удК 342.5

DOI https://doi.org/10.32837/apdp.v0i90.3222

Д. П.Філіпський

\title{
ВИЗНАЧЕННЯ МЕЖ ПАРЛАМЕНТСЬКОЇ КОМПЕТЕНЦІЇ ЯК ЗАПОРУКИ ОБМЕЖЕННЯ ДЕРЖАВНОЇ ВЛАДИ
}

В умовах створення фундаменту правової держави дуже важливо привернути увагу вчених-правознавців до багатостороннього аналізу питань стосовно самостійності держави і меж втручання парламенту в справи суспільства й особистості.

Усе це актуалізує відоме в теорії права питання про творчі можливості парламенту в розвитку суспільних відносин, тобто про межі діяльності парламенту. Важливо знати, що законодавцю заборонено (відповідно, що дозволено) природою суспільних відносин, що може порушити стабільність правової системи, зруйнувати умови, при яких люди можуть нормально будувати свої взаємини. Зважаючи на це, треба визначити, якою має бути діяльність, що відповідає реальним потребам учасників суспільних відносин і природі останніх. Інакше кажучи, йдеться про заборонені межі, «кордони», переступати які парламент не має права. Звичайно, знання кордонів та заборон ще не означає, що законодавець буде дотримуватися цих умов. Але без їх визначення втрачає сенс існування інституту конституційного контролю, оскільки він можливий лише в тому випадку, якщо встановлені якісні межі контрольованого процесу, його «координати» в єдиному соціальному організмі.

Під межами діяльності парламенту розуміється, по-перше, які суспільні відносини можуть бути піддані впливу з боку законодавця, по-друге, які принципові можливості, а отже, межі впливу законодавця на ці суспільні відносини

Відомо, що найбільші античні мислителі Платон і Арістотель не розрізняли поняття «суспільство» і «держава», тому в їх вченнях питання про межі діяльності законодавця як наукова проблема не ставилася. Звідси зрозуміло, чому Платон, конструюючи ідеальну справедливу державу (в діалозі «Держава»), вважав, що вона має право вирішувати практично будь-які проблеми суспільства (вводити спільність дружин і дітей, регламентувати питання побуту, власності, праці, виховувати громадян тощо) [1].

Арістотель не поділяв думки Платона, вважаючи, що це призведе до загибелі держави, але виходив в своїх поглядах з того, що держава є вища форма спілкування, що охоплює всі інші форми спілкування. Характеризуючи форми держави, Арістотель прийшов до висновку про те, що законодавець держави повинен прагнути до того, щоб надати громадянам дозвілля і світ, «оскільки кінцевою метою війни служить світ, роботи - дозвілля» [1].

У гносеологічному плані постановка проблеми про межі діяльності законодавця стала можливою тоді, коли філософська і політична думка стала послідовно виходити з відмінності громадянського суспільства і держави. У доктринах мислителів, які дотримувалися договірної теорії походження держави і права, а також принципу поділу влади, питання про межі втручання законодавця в справи суспільства є органічною частиною їх концепцій.

(c) Д. П. Філіпський, 2021 
Дж. Лок спирався на те, що влада законодавчого органу ніколи не може сягати далі, ніж це необхідно для загального блага. «Ця влада, в своїх крайніх межах обмежена суспільним благом. Вона не має іншої мети, крім збереження суспільства, i, отже, ніколи не може мати право знищувати, поневолювати або навмисно розоряти підданих» [2]. Не оминув у своєму вченні про право це питання й I. Кант. Загальний принцип, яким обмежується влада законодавця, він сформулював так: «чого народ не може вирішити відносно самого себе, того і законодавець не може вирішити відносно народу» [3].

Г.В. Геґель не сформулював, як І. Кант, загального принципу (постулату), що визначає межі діяльності законодавчої влади, але у вченні про право він послідовно вказував на ті сфери життя суспільства, які не можуть бути предметом позитивного законодавства. Так, він вважав, що «моральна сторона» життя суспільства і моральні заповіді не повинні піддаватися впливу з боку законодавця. Суть позиції Г.В. Гегеля в даному питанні зводиться до того, що впливу з боку законодавця можуть бути піддані лише зовнішні сторони суспільних відносин. «У відносинах шлюбу, любові, релігії, можуть стати предметом законодавства лише ті ... які за своєю природою здатні мати в собі зовнішню сторону»[4].

Але якщо в концепціях названих мислителів питання про межі діяльності законодавця розглядався в якості необхідного, складеного елементу праворозуміння (I. Кант, Г.В. Геґель) або в контексті договірної теорії утворення держави (Дж. Лок), то низка дослідників присвятили йому окремі роботи. Серед них варто виділити працю Дж.Ст. Мілля «Про свободу», роботу Мірабо «Про публічне виховання», дослідження професора Едуарда Лабуле «Держава та їі межі» .

Вільгельм фон Гумбольдт присвятив цій проблемі фундаментальну працю «Про межі державної діяльності», вважаючи, що виявлення цілей і меж діяльності держави може бути більш важливо, ніж дослідження політичної проблеми.

Звісно ж, що погляди кожного з названих дослідників заслуговують спеціального аналізу, оскільки багато хто з висловлених ними ідей з питань, що стосуються можливостей законодавця в регулюванні суспільних відносин, мають не тільки пізнавальне значення, але можуть бути використані в практиці законотворчості при створенні соціалістичної правової держави. У межах статті вважаємо за необхідне зупинитися більш докладно на ідеях, висловлених В. Гумбольдтом.

Питання про межі діяльності держави В. Гумбольдт вирішував, виходячи з аналізу їі цілей. «Мета держави може бути двоякою: вона може прагнути сприяти щастю громадян або лише запобігати злу, що заподіюється громадянам природою або людьми» [5, с. 89]. Прагнення держави ощасливити громадян, вважав він, все більше посилює ïi вплив на них, що в свою чергу призводить до шкідливих наслідків, бо вбиває ініціативу і послаблює силу нації. Гумбольдт - прихильник того, щоб держава в своїй діяльності не виходила за межі, які поставлені необхідністю запобігати небезпеці, що загрожує громадянам як від внутрішніх, так і від зовнішніх ворогів. Таким чином, призначення законодавця полягає в тому, щоб надати громадянам цілковиту свободу.

Розуміючи, що під приводом гарантування безпеки держава все ж може обмежити свободу громадян, В. Гумбольдт спробував чітко визначити теоретично 
можливі випадки порушення безпеки і тим самим захистити громадян від спроб держави зазіхнути на їх свободу. Його висновок зводиться до того, що безпека громадян порушується діями, які або самі по собі порушують їх право або наслідки яких можуть до цього призвести. Держава в цьому випадку має лише забороняти і запобігати діям того чи іншого роду, а якщо вони вчинені, спробувати законним шляхом відшкодувати завдані збитки і за допомогою покарання домогтися того, щоб в майбутньому порушення стали рідшими [6, с. 244].

В. Гумбольдт - прихильник світської держави, тому «... все, що стосується релігії, лежить поза межами діяльності держави ... проповідники, як і взагалі всі богослужіння в цілому, повинні перебувати у віданні громад і не підлягати контролю держави». Держава, відповідно, повинна повністю утримуватися від спроб прямо чи опосередковано впливати на звичаї і характер нації, але, якщо це не є природним і неминучим наслідком їі інших, абсолютно необхідних заходів [6, с. 287].

У вченні К. Маркса про державу і право проблема меж діяльності законодавця розглядається як складовий елемент праворозуміння. К. Маркс в ранніх роботах проводив чітке розходження між правом і законом. Закон в його розумінні обумовлений правом, i, отже, законодавець пов'язаний в своїх діях «правовою природою речей». «Законодавець повинен дивитися на себе як на натураліста. Він не робить законів, він не винаходить їх, а тільки формулює, він виражає в свідомих позитивних законах внутрішні закони духовних відносин» [7, с. 523]. У розумінні Маркса межі діяльності законодавця задаються природно-історичним розвитком правової форми суспільних відносин. Оскільки цей розвиток підпорядкований певного роду закономірностям, то вони і складають ті кордони, переступати які законодавець не має права.

Між суспільством і громадянами, з одного боку, і державою-законодавцем, з іншого, природно-історичним чином складається двосторонні правовідносини. При цьому як суспільство в цілому, так і кожен громадянин окремо вправі вимагати від законодавця таких законів, які б мали правовий характер. У свою чергу вони, безумовно, зобов'язані їх виконувати. Законодавець, в свою чергу, зобов'язаний осягнути правову природу речей, відкрити і сформулювати закономірності, що керують розвитком суспільних відносин в правовій державі. У той же час він має право вимагати від суспільства в цілому і від кожного з його членів суворого дотримання прийнятих ним законів.

Звичайно, дані правовідносини не функціонують як правовідносини в класичному сенсі слова i, напевно, більш правильно розглядати подібний взаємозв'язок суспільства і законодавця як певний правовий імператив. Цілком можливо, що саме цей імператив лежить в основі одного з принципів правової держави - принципу взаємної відповідальності громадянина і держави. Характер цих відносин не може бути наслідком волі як особи, так і держави. Справа в тому, що в обох випадках принцип взаємної відповідальності перетворюється на свою протилежність - диктат однієї зі сторін. В.С. Нерсесянц правильно зазначає, що відносини держави і особи мають правовий характер, є складовою частиною права, що об'єктивно складається в конкретному суспільстві [8]. 
Сфера дії права існує як об'єктивна реальність незалежно від того, усвідомлюємо ми її чи ні. Поряд зі сферою дії права є і сфера законодавчого регулювання, тобто ті правові суспільні відносини, які були (або можуть бути) піддані впливу з боку законодавця. Законодавець надає їм законної сили, підводить під захист держави, стверджує в суспільній свідомості той факт, що відносини мають визначений правом характер.

Якби правова природа суспільних відносин лежала на поверхні або була у всіх випадках науково доведена, то сфера законодавчого регулювання скоріше за все збіглася б зі сферою дії права. Але досвід розвитку законодавчого регулювання суспільних відносин свідчить про те, що найчастіше обидві зазначені сфери не збігаються. Доказом їх розбіжності можуть служити інститути аналогії права, аналогії закону, поняття «неправового закону» [9].

Отже, у правовій державі законодавець не може претендувати на безконтрольну законотворчість. Завдання юридичної науки і практики конституційного права - знайти і сформулювати межі діяльності законодавця, створити соціально-політичні, організаційні та правові механізми контролю за їх дотриманням.

\section{Jimepamypa}

1. История политических и правовых учений : учебник / отв. ред. Нерсесянц B. C. URL: http:// library.khpg.org/files/docs/1380635715.pdf.

2. Локк Дж. Два трактата о правлении. URL: https://www.civisbook.ru/files/File/Lokk Traktaty_2.pdf

3. Кант И. К вечному миру : сборник. URL: https://tinyurl.com/kz43cye8.

4. Весь Гегель: Наука логики, Философия права, Философия истории. URL: https://tinyurl.com/ $4 \times 5 f p 5 k 7$.

5. Гумбольдт В. О пределах государственной деятельности. Челябинск : Социум, 2009. 287 с.

6. Гумбольдт В. Язык и философия культуры. Москва, Прогресс, 1985. 452 с.

7. Чичерин Б. Н. История политических учений. Санкт-Петербург. Издательство РХГА, 2010. T. $3.784 \mathrm{c}$.

8. История политических и правовых учений : учебник / отв. ред. Нерсесянц B. C. URL: http:// library.khpg.org/files/docs/1380635715.pdf.

9. Радбрух Г. Законне неправо та надзаконне право. URL: http://dspace.nbuv.gov.ua/bitstream/ handle/123456789/9678/09-Radbruch.pdf?sequence=1.

\section{Анотація}

Філіпський Д. П. Визначення меж парламентської компетенції як запоруки обмеження державної влади. - Стаття.

У статті автор здійснює аналіз меж парламентської компетенції як запоруки обмеження державної влади. Питання щодо меж діяльності парламенту є дуже актуальним у науці конституційного права. Важливо знати, що законодавцю заборонено (відповідно, що дозволено) природою суспільних відносин, що може порушити стабільність правової системи, зруйнувати умови, за яких люди можуть нормально будувати свої взаємини. Зважаючи на це, треба визначити, якою має бути діяльність, що відповідає реальним потребам учасників суспільних відносин і природі останніх. Інакше кажучи, йдеться про заборонені межі, «кордони», переступати які парламент не має права.

Автор наводить історичну парадигму підходів до зазначеного питання. Починаючи з античних філософів - Платона й Арістотеля, розрізняли поняття "суспільство» і «держава», тому в їх вченнях питання про межі діяльності законодавця як наукова проблема не ставилася.

В епоху Відродження філософ Джон Лок спирався на те, що влада законодавчого органу ніколи не може сягати далі, ніж це необхідно для загального блага.

Представник німецької класичної філософії, Георг Гегель вважав, що впливу з боку законодавця можуть бути піддані лише зовнішні сторони суспільних відносин. 
Дуже грунтовним підходом щодо досліджуваного питання відзначився Вільгельм фон Гумбольдт. Питання про межі діяльності держави В. Гумбольдт вирішував, виходячи з аналізу їі цілей. Гумбольдт - прихильник того, щоб держава в своїй діяльності не виходила за межі, які поставлені необхідністю запобігати небезпеці, що загрожує громадянам як від внутрішніх, так і від зовнішніх ворогів. Таким чином, призначення законодавця полягає в тому, щоб надати громадянам цілковиту свободу.

Підсумовуючи, автор доходить висновків, що в правовій державі законодавець не може претендувати на безконтрольну законотворчість. Завдання юридичної науки і практики конституційного права - знайти і сформулювати межі діяльності законодавця, створити соціально-політичні, організаційні та правові механізми контролю за їх дотриманням.

Ключові слова: обмеження влади, парламент, компетенція, межі, держава.

\section{Summary}

Filipskyi D. P. Defining the limits of parliamentary competence as a guarantee of restricting state power. - Article.

In the article the author analyzes the limits of parliamentary competence as a guarantee of limiting state power. The question of the limits of parliamentary activity is very relevant in the science of constitutional law. It is important to know that the legislator is forbidden (respectively, what is allowed) by the nature of public relations, which can disrupt the stability of the legal system, destroy the conditions under which people can build their relationships. Based on this, it is necessary to determine what should be the activities that meet the real needs of participants in public relations and the nature of the latter. In other words, we are talking about forbidden borders, "borders", which the parliament has no right to cross.

The author gives a historical paradigm of approaches to this issue. Beginning with the ancient philosophers - Plato and Aristotle, distinguished between the concepts of "society" and "state", so in their teachings the question of the limits of the legislator as a scientific problem was not raised.

In the Renaissance, the philosopher John Locke assumed that the power of the legislature could never go beyond what is necessary for the common good.

A representative of German classical philosophy, Georg Hegel believed that the influence of the legislator can be exposed only to external aspects of social relations.

Wilhelm von Humboldt took a very thorough approach to the research question. The question of the limits of the state W. Humboldt decided based on the analysis of its goals. Humboldt is a supporter of the state not to go beyond the limits set by the need to prevent the danger that threatens citizens from both internal and external enemies. Thus, the purpose of the legislator is to give citizens complete freedom.

Summing up, the author comes to the conclusion that in a state governed by the rule of law, the legislator cannot claim uncontrolled lawmaking. The task of legal science and practice of constitutional law is to find and formulate the limits of the legislator's activity, to create socio-political, organizational and legal mechanisms of control over their observance.

Key words: restrictions of state power, parliament, competence, limits, state. 